\title{
Stigma Masyarakat terhadap Orang dengan HIV/AIDS
}

\author{
Public Stigma to People Living with HIV/AIDS
}

Zahroh Shaluhiyah, Syamsulhuda Budi Musthofa, Bagoes Widjanarko

Program Studi Magister Promosi Kesehatan Fakultas Kesehatan Masyarakat Universitas Diponegoro

\begin{abstract}
Abstrak
Kabupaten Grobogan merupakan kabupaten dengan peningkatan kasus HIVIAIDS cukup tajam dibandingkan kabupaten lain di Jawa Tengah. Penelitian ini bertujuan untuk mengidentifikasi stigma masyarakat terhadap orang dengan HIVIAIDS (ODHA) dan faktor yang memengaruhinya. Penelitian explanatory ini dilakukan melalui pendekatan studi potong lintang dengan sampel berjumlah 300 kepala keluarga yang dipilih menggunakan sampel acak proporsional pada tiga kelurahan dengan kasus HIV tertinggi selama Agustus - September 2014. Pengumpulan data dilakukan melalui wawancara tatap muka menggunakan kuesioner terstruktur. Sedangkan analisis data dilakukan secara univariat, bivariat menggunakan kai kuadrat, dan multivariat menggunakan regresi logistik. Sebagian besar responden adalah laki-laki dengan tingkat pendidikan terbanyak sekolah menengah atas ke bawah. Separuh responden masih memberikan stigma terhadap ODHA. Responden dengan keluarga yang memberikan stigma memiliki kemungkinan memberikan stigma terhadap ODHA empat kali lebih besar dibandingkan responden yang keluarganya tidak memberikan stigma. Demikian juga responden yang berpersepsi negatif terhadap ODHA memiliki kemungkinan memberikan stigma dua kali lebih besar dibandingkan yang berpersepsi positif. Faktor sikap tetangga dan tokoh masyarakat terhadap ODHA juga berhubungan signifikan dengan stigma responden terhadap ODHA. Kesimpulannya adalah sikap keluarga dan persepsi responden terhadap ODHA merupakan faktor yang berpengaruh pada munculnya stigma terhadap ODHA sehingga disarankan adanya pemberian informasi tentang HIVIAIDS yang lengkap kepada keluarga dan masyarakat untuk menurunkan atau menghilangkan stigma.
\end{abstract}

Kata kunci: HIVIAIDS, stigma masyarakat, orang dengan HIVIAIDS

\section{Abstract}

Grobogan District is a district with a sharp increasing of HIVIAIDS case compared to other districts over Central Java. This study aimed to identify public stigma to people living with HIVIAIDS (PLWHA) and influencing fac- tors. This explanatory study was conducted using cross sectional design worth 300 family head samples selected by using proportional random sampling on three subdistricts with highest HIV case within August - September 2014. Data collecting was conducted through face-to-face interview using structured questionnaire. Meanwhile, data analysis was conducted in univariate, bivariate using chi square and multivariate using logistic regression. Most respondents were men whose education level was mostly high school to the bottom level. Half of respondents were still stigmatizing PLWHA. Respondents whose families stigmatized had possibility of stigmatizing four times bigger than respondents whose families did not. Similarly, respondents holding negative perceptions toward PLWHA had possibility of stigmatizing twice bigger than those holding positive perceptions. Attitude of neighbors and public figures toward PLWHA also significantly related to respondent's stigma to PLWHA. To sum up, family attitude and respondent's perception to PLWHA were influencing factors of emerging stigma toward PLWHA. Therefore, it suggested that providing families and public any complete information about HIVIAIDS may decrease or remove the stigma.

Keywords: HIVIAIDS, public stigma, people living with HIVIAIDS

\section{Pendahuluan}

Salah satu hambatan paling besar dalam pencegahan dan penanggulangan Human Imunnodeficiency Virus/Acquired Immune Deficiency Syndrome (HIV/AIDS) di Indonesia adalah masih tingginya stigma dan diskriminasi terhadap orang dengan HIV/AIDS (ODHA). Stigma berasal dari pikiran seorang individu atau masyarakat yang memercayai bahwa penyakit AIDS merupakan akibat dari perilaku amoral yang tidak dapat

Korespondensi: Zahroh Shaluhiyah, Prodi Magister Promosi Kesehatan FKM Universitas Diponegoro, Gedung Pascasarja Undip Lantai $3 \mathrm{Jl}$. Imam Barjo, SH No. 3 Semarang, No.Telp:024-8417993,e-mail: shaluhiyah.zahroh@gmail.com 
diterima oleh masyarakat. Stigma terhadap ODHA tergambar dalam sikap sinis, perasaan ketakutan yang berlebihan, dan pengalaman negatif terhadap ODHA. Banyak yang beranggapan bahwa orang yang terinfeksi HIV/AIDS layak mendapatkan hukuman akibat perbuatannya sendiri. Mereka juga beranggapan bahwa ODHA adalah orang yang bertanggung jawab terhadap penularan HIV/AIDS. ${ }^{1}$ Hal inilah yang menyebabkan orang dengan infeksi HIV menerima perlakuan yang tidak adil, diskriminasi, dan stigma karena penyakit yang diderita. Isolasi sosial, penyebarluasan status HIV dan penolakan dalam pelbagai lingkup kegiatan kemasyarakatan seperti dunia pendidikan, dunia kerja, dan layanan kesehatan merupakan bentuk stigma yang banyak terjadi.1-3 Tingginya penolakan masyarakat dan lingkungan akan kehadiran orang yang terinfeksi HIV/AIDS menyebabkan sebagian ODHA harus hidup dengan menyembunyikan status. ${ }^{1,4,5}$

Stigma terhadap ODHA memiliki dampak yang besar bagi program pencegahan dan penanggulangan HIV/AIDS termasuk kualitas hidup ODHA. Populasi berisiko akan merasa takut untuk melakukan tes HIV karena apabila terungkap hasilnya reaktif akan menyebabkan mereka dikucilkan. Orang dengan HIV positif merasa takut mengungkapkan status HIV dan memutuskan menunda untuk berobat apabila menderita sakit, yang akan berdampak pada semakin menurunnya tingkat kesehatan mereka dan penularan HIV tidak dapat dikontrol. Dampak stigma dan diskriminasi pada perempuan ODHA yang hamil akan lebih besar ketika mereka tidak mau berobat untuk mencegah penularan ke bayinya.

Provinsi Jawa Tengah merupakan provinsi terbanyak keenam jumlah kumulatif kasus HIV/AIDS di Indonesia. Sampai dengan Maret 2014, jumlah kumulatif infeksi HIV sebesar 7.584, sedangkan jumlah kumulatif AIDS sebanyak 3.339 kasus dengan 978 kasus kematian AIDS. ${ }^{6}$ Masih tingginya kematian ini kemungkinan besar disebabkan karena ODHA tidak memiliki kesempatan mendapatkan perawatan yang optimal akibat masih tingginya stigma di kalangan masyarakat.

Kabupaten Grobogan merupakan salah satu kabupaten di Jawa Tengah yang dipilih menjadi area studi karena peningkatan kasus HIV/AIDS yang cukup tinggi dibandingkan kabupaten lain. Saat ini, Kabupaten Grobogan menduduki peringkat keempat kota/kabupaten dengan kumulatif kasus HIV/AIDS terbanyak di Provinsi Jawa Tengah. Sampai dengan Juni 2014, jumlah kasus HIV sebesar 221 kasus, sedangkan AIDS sejumlah 288 kasus. $^{7}$

Kabupaten Grobogan merupakan salah satu kabupaten dengan perkembangan sosial ekonomi yang lambat berkaitan dengan kondisi geografis berupa bukit kapur yang tandus. Sebagian besar masyarakat bekerja sebagai tenaga kerja informal di luar wilayah Grobogan. Rendahnya pengetahuan dan keterampilan menyebabkan banyaknya masyarakat Grobogan yang menjadi pekerja migran ke kota besar seperti Jakarta, Medan, bahkan ke luar negeri. Hal ini menyebabkan mereka jauh dari keluarga dan memudahkan mereka melakukan perilaku seksual berisiko, seperti ditunjukkan dengan kasus infeksi menular seksual (IMS) dan HIV yang semakin meningkat setiap tahun.

Dengan pengetahuan dan pendidikan yang rendah, stigma dan diskriminasi ODHA masih banyak terjadi di masyarakat Kabupaten Grobogan. Sebagai contoh, apabila diketahui terdapat ODHA yang meninggal, akan sulit mencari orang yang bersedia untuk melaksanakan pemulasaran jenazah. Demikian juga banyak masyarakat yang menolak bersahabat dengan ODHA. Walaupun tidak sampai terjadi pengusiran ODHA dari lingkungan, namun masih banyak masyarakat yang enggan melibatkan ODHA dalam kegiatan masyarakat.

Banyak faktor yang memengaruhi terjadinya stigma pada ODHA di masyarakat. Pendidikan kesehatan yang bertujuan meningkatkan pengetahuan mengenai HIV/AIDS dalam banyak penelitian dibuktikan sebagai salah satu faktor yang paling memengaruhi terjadinya pengurangan stigma. 8,9 Orang yang memiliki pengetahuan cukup tentang faktor risiko, transmisi, pencegahan, dan pengobatan HIV/AIDS cenderung tidak takut dan tidak memberikan stigma terhadap ODHA. $8,10,11$

Selain pengetahuan yang kurang, pengalaman atau sikap negatif terhadap penularan HIV dianggap sebagai faktor yang dapat memengaruhi munculnya stigma dan diskriminasi. Pendapat tentang penyakit AIDS merupakan penyakit kutukan akibat perilaku amoral juga sangat memengaruhi orang bersikap dan berperilaku terhadap ODHA. 8,12,13

Stigma terhadap ODHA adalah suatu sifat yang menghubungkan seseorang yang terinfeksi HIV dengan nilai-nilai negatif yang diberikan oleh mereka (masyarakat). Stigma membuat ODHA diperlakukan secara berbeda dengan orang lain. Diskriminasi terkait HIV adalah suatu tindakan yang tidak adil pada seseorang yang secara nyata atau diduga mengidap HIV. ${ }^{14}$

Berdasarkan informasi dan data tersebut, maka penelitian ini dilakukan dengan tujuan untuk menganalisis faktor yang memengaruhi terjadinya stigma masyarakat terhadap ODHA di Kabupaten Grobogan. Diharapkan hasil dari penelitian ini dapat memberikan masukan kepada pembuat kebijakan untuk mendukung program pengurangan stigma kepada ODHA sehingga memudahkan ODHA untuk mengungkapkan status dan memudahkan pengobatan serta pencegahan penularan kepada masyarakat hingga pada akhirnya akan membantu meningkatkan kualitas hidup ODHA. 


\section{Metode}

Jenis penelitian ini merupakan riset explanatory untuk menemukan penjelasan tentang suatu kejadian stigma ODHA dengan pendekatan potong lintang. Pengambilan data penelitian dilakukan selama satu bulan, yaitu bulan Agustus sampai dengan September 2014, sedangkan pengambilan sampel dilakukan dengan menggunakan tabel Isaac and Michael dengan derajat kemaknaan $10 \%$. Dalam tabel Isaac and Michael, dengan jumlah populasi antara 20.000 - 25.000 orang dan derajat kemaknaan sebesar $10 \%$, jumlah sampel yang dapat diambil sebanyak 270 orang. Untuk menghindari drop out sample, maka sampel ditambah sebesar $10 \%$ sehingga jumlah sampel menjadi 297 dan dibulatkan menjadi 300 sampel. Sebanyak 300 kepala keluarga dipilih secara propotional random sampling dari tiga kelurahan dengan jumlah penderita HIV tertinggi di Kabupaten Grobogan. Instrumen penelitian menggunakan kuesioner terstruktur dengan mewawancarai responden. Kriteria inklusi dalam penelitian ini adalah kepala rumah tangga yang tinggal di salah satu dari tiga kelurahan terpilih dan bersedia menjadi responden dengan menandatangani informed consent. Sedangkan kriteria eksklusi dalam penelitian ini adalah kepala keluarga yang tinggal di tiga kelurahan terpilih, namun menolak untuk diwawancarai serta tidak berada di tempat atau di rumah saat penelitian dilakukan.

Penelitian ini berlokasi di tiga kelurahan yaitu Kelurahan Purwodadi, Kelurahan Danyang, dan Kelurahan Kuripan yang merupakan kelurahan dengan angka kejadian HIV terbanyak di antara kelurahan lain. Pengumpulan data dilakukan dengan menggunakan kuesioner terstruktur melalui wawancara tatap muka kepada 300 kepala rumah tangga terpilih.

Penelitian ini menggunakan teori Lawrence Green sebagai referensi kerangka konsep dengan melibatkan variabel faktor predisposing, enabling, dan reinforcing, yang meliputi pengetahuan tentang IMS dan HIV/AIDS serta persepsi terhadap ODHA, akses sumber informasi HIV/AIDS, persepsi responden terhadap sikap dan perilaku tetangga, keluarga, dan tokoh masyarakat terhadap ODHA. Sedangkan karakteristik responden meliputi usia, jenis kelamin, pendidikan, pekerjaan, dan pendapatan.

Stigma diukur berdasarkan beberapa pertanyaan, di antaranya bila tinggal dekat dengan ODHA, menyentuh tubuh ODHA, tidur dalam satu ruangan dengan ODHA, anak bermain dengan anak ODHA, merawat ODHA dengan pilihan jawaban takut, tidak takut. Selain itu, juga ditanyakan bila keluarga, tetangga, teman, teman anak menjadi ODHA; pendapat responden bila ODHA dikucilkan oleh masyarakat, didiskriminasi oleh petugas apabila nama ODHA disebarluaskan agar dapat dihindari dengan pilihan jawaban mendukung, tidak mendukung.
Analisis data dilakukan dengan uji statistik univariat memakai distribusi frekuensi, hubungan antarvariabel yang diuji dengan menggunakan uji statistik kai kuadrat dan uji statistik multivariat dengan menggunakan uji regresi logistik berganda.

\section{Hasil}

Stigma terhadap ODHA masih banyak terjadi di masyarakat. Hal ini terlihat dari hasil penelitian yang menunjukkan hampir separuh dari responden $(49,7 \%)$ memiliki sikap negatif terhadap ODHA. Bentuk stigma di antaranya tidak bersedia makan makanan yang disediakan atau dijual oleh ODHA, tidak membolehkan anaknya bermain bersama dengan anak HIV, tidak mau menggunakan toilet bersama dengan ODHA, bahkan menolak untuk tinggal dekat dengan orang yang menunjukkan gejala HIV/AIDS. Apabila terdapat ODHA dalam keluarga, mereka merasa takut untuk tidur bersama dengan ODHA dan tidak bersedia merawat seperti menyiapkan makanan dan membersihkan peralatan makan, serta duduk dekat dengan orang-orang terinfeksi HIV yang tidak menunjukkan gejala sakit.

Distribusi hasil uji statistik univariat berdasarkan karakteristik menunjukkan bahwa responden dalam penelitian ini terbagi dalam dua kelompok usia dengan jumlah yang hampir sama, jumlah responden laki-laki enam kali lipat lebih banyak daripada responden perempuan. Responden dengan pendidikan tinggi hanya sebesar $11,3 \%$ dan sebagian besar responden berpendidikan rendah (tamat sekolah dasar). Terkait dengan tingkat pendapatan, sebagian besar responden memiliki pendapatan di atas upah minimum Kabupaten Grobogan (Tabel 1).

Hasil distribusi frekuensi faktor determinan stigma terhadap ODHA menunjukan bahwa mayoritas pengetahuan responden tentang IMS dan HIV/AIDS masih kurang, namun sebagian besar responden pernah mendapat akses informasi tentang HIV/AIDS dan memiliki persepsi positif terhadap ODHA. Tetangga merupakan salah satu orang terdekat ODHA dalam lingkup interaksi sosial. Hampir separuh responden berpendapat bahwa banyak tetangga mereka juga memiliki sikap dan perilaku

Tabel 1. Distribusi Berdasarkan Karakteristik Responden

\begin{tabular}{llll}
\hline Karakteristik & Kategori & n & $\%$ \\
\hline \multirow{2}{*}{ Usia } & $<46$ tahun & 149 & 49,7 \\
\multirow{3}{*}{ Jenis kelamin } & $\geq 46$ tahun & 151 & 50,3 \\
& Laki-laki & 258 & 86,0 \\
Pendidikan & Perempuan & 42 & 14,0 \\
& Tidak sekolah & 24 & 8,0 \\
& Pendidikan dasar (SD) & 139 & 46,3 \\
& Pendidikan menengah (SMP \& SMA) & 103 & 34,3 \\
\multirow{3}{*}{ Pendapatan } & Pendidikan tinggi & 34 & 11,3 \\
& Kurang dari UMK (<Rp 935.000,-) & 64 & 21,3 \\
& Lebih dari UMK ( $\geq$ Rp 935.000,-) & 236 & 78,7 \\
\hline
\end{tabular}


Tabel 2. Distribusi Faktor Determinan Stigma Masyarakat terhadap ODHA

\begin{tabular}{|c|c|c|c|c|c|c|c|c|}
\hline \multirow{3}{*}{ Variabel } & \multirow{3}{*}{ Kategori } & \multirow{3}{*}{$\mathbf{n}$} & \multirow{3}{*}{$\%$} & \multicolumn{4}{|c|}{ Stigma Masyarakat terhadap ODHA } & \multirow{3}{*}{ Nilai $p$} \\
\hline & & & & \multicolumn{2}{|c|}{ Ya } & \multicolumn{2}{|c|}{ Tidak } & \\
\hline & & & & $\mathbf{n}$ & $\%$ & $\mathbf{n}$ & $\%$ & \\
\hline \multirow[t]{2}{*}{ Pengetahuan IMS dan HIV/AIDS } & Kurang & 160 & 53,3 & 82 & 51,3 & 78 & 48,8 & 0,638 \\
\hline & Baik & 140 & 46,7 & 67 & 47,9 & 73 & 52,1 & \\
\hline \multirow[t]{2}{*}{ Persepsi tentang ODHA } & Negatif & 129 & 43,0 & 76 & 58,9 & 53 & 41,1 & 0,008 \\
\hline & Positif & 171 & 57,0 & 73 & 42,7 & 98 & 57,3 & \\
\hline \multirow{2}{*}{ Akses informasi tentang HIV/AIDS } & Kurang mengakses & 109 & 36,3 & 53 & 48,6 & 56 & 51,4 & 0,879 \\
\hline & Mengakses & 191 & 63,7 & 96 & 50,3 & 95 & 49,7 & \\
\hline \multirow[t]{2}{*}{ Faktor sikap tetangga terhadap ODHA } & Negatif & 148 & 49,3 & 90 & 60,8 & 58 & 39,2 & 0,001 \\
\hline & Positif & 152 & 50,7 & 59 & 38,8 & 93 & 61,2 & \\
\hline \multirow[t]{2}{*}{ Faktor sikap keluarga terhadap ODHA } & Negatif & 138 & 46,0 & 93 & 67,4 & 45 & 32,6 & 0,001 \\
\hline & Positif & 162 & 54,0 & 56 & 34,6 & 106 & 65,4 & \\
\hline Faktor sikap tokoh masyarakat terhadap & Negatif & 75 & 25,0 & 48 & 64,0 & 27 & 36,0 & 0,006 \\
\hline ODHA & Positif & 225 & 75,0 & 101 & 44,9 & 124 & 55,1 & \\
\hline
\end{tabular}

Tabel 3. Analisis Multivariat Determinan Stigma Masyarakat terhadap ODHA

\begin{tabular}{|c|c|c|c|c|c|c|c|}
\hline \multirow{2}{*}{ Variabel Independen } & \multirow{2}{*}{ B } & \multirow{2}{*}{ SE } & \multirow{2}{*}{ Wald } & \multirow{2}{*}{ Sig. } & \multirow{2}{*}{$\operatorname{Exp}(B)$} & \multicolumn{2}{|c|}{ 95\% CI for $\operatorname{EXP}(B)$} \\
\hline & & & & & & Lower & Upper \\
\hline Persepsi responden terhadap ODHA & 0,495 & 0,251 & 3,900 & 0,048 & 1,640 & 1,004 & 2,681 \\
\hline Faktor sikap stigma tetangga & $-0,120$ & 0,367 & 0,107 & 0,744 & 0,887 & 0,432 & 1,820 \\
\hline Faktor sikap stigma keluarga & 1,339 & 0,373 & 12,905 & 0,000 & 3,815 & 1,837 & 7,919 \\
\hline Faktor sikap stigma tokoh masyarakat & 0,145 & 0,322 & 0,203 & 0,653 & 1,156 & 0,615 & 2,175 \\
\hline
\end{tabular}

negatif (memberikan stigma) terhadap ODHA, sedangkan keluarga lebih banyak memberikan sikap positif terhadap ODHA. Sejalan dengan sikap keluarga terhadap ODHA, sebagian besar tokoh masyarakat juga memiliki sikap positif terhadap ODHA (Tabel 2).

Hasil analisis hubungan atau bivariat menggunakan kai kuadrat menunjukkan terdapat empat variabel yang memiliki hubungan bermakna dengan stigma terhadap ODHA (nilai $p<0,05$ ), yaitu persepsi responden tentang ODHA, faktor sikap tetangga terhadap ODHA, faktor sikap keluarga terhadap ODHA, dan faktor sikap tokoh masyarakat terhadap ODHA. Sedangkan pengetahuan tentang IMS dan HIV/AIDS dan akses informasi tentang HIV/AIDS tidak memiliki hubungan yang bermakna dengan stigma responden terhadap ODHA, nilai $\mathrm{p}=$ 0,638 dan nilai $\mathrm{p}=0,879$ (Tabel 2).

Hasil uji multivariat dengan menggunakan regresi logistik menunjukkan bahwa persepsi responden terhadap ODHA dan faktor sikap keluarga terhadap ODHA merupakan variabel yang berpengaruh pada stigma terhadap ODHA. Keluarga yang memiliki sikap negatif terhadap ODHA memiliki kemungkinan empat kali lebih besar memberikan stigma dibandingkan dengan keluarga yang memiliki sikap positif terhadap ODHA. Demikian juga responden yang memiliki persepsi negatif terhadap ODHA memiliki kemungkinan dua kali lebih besar memberikan stigma terhadap ODHA dibandingkan dengan responden yang memiliki persepsi positif (Tabel 3).

\section{Pembahasan}

Stigma terhadap ODHA dalam penelitian ini adalah sikap dan perilaku negatif seseorang apabila berhadapan dengan ODHA. Fokus penelitian ini adalah mengidentifikasi bentuk stigma masyarakat terhadap ODHA dan menganalisis hubungan faktor determinan yang berkontribusi terhadap stigma masyarakat pada ODHA yang masih banyak terjadi di masyarakat.

Stigma muncul karena tidak tahunya masyarakat tentang informasi HIV yang benar dan lengkap, khususnya dalam mekanisme penularan HIV, kelompok orang berisiko tertular HIV dan cara pencegahannya termasuk penggunaan kondom. ${ }^{13,15}$ Stigma merupakan penghalang terbesar dalam pencegahan penularan dan pengobatan HIV. Selain itu, stigma terhadap ODHA juga menyebabkan orang yang memiliki gejala atau diduga menderita HIV enggan melakukan tes untuk mengetahui status HIV karena apabila hasilnya positif, mereka takut akan ditolak oleh keluarga dan khususnya oleh pasangan. Munculnya stigma di masyarakat juga merupakan salah satu kendala yang dihadapi dalam penanggulangan HIV/AIDS. 1,16,17

Dalam hidup bermasyarakat, stigma juga menghalangi ODHA untuk melakukan aktivitas sosial. ODHA menutup diri dan cenderung tidak bersedia melakukan interaksi dengan keluarga, teman, dan tetangga. Hal ini disebabkan karena sebagian masyarakat beranggapan bahwa orang dengan HIV positif adalah orang berperi- 
laku tidak baik seperti perempuan pekerja seksual, pengguna narkoba, dan homoseksual. Kelompok ini oleh sebagian masyarakat dianggap memengaruhi epidemi HIV/AIDS dan membuat masyarakat menjadi menolak dan membenci kelompok tersebut. 13,15,16,18

Lebih dari separuh responden dalam penelitian ini memiliki pengetahuan yang kurang tentang IMS dan HIV/AIDS dengan adanya beberapa pemahaman yang masih salah, seperti HIV dapat ditularkan melalui pakaian atau benda-benda yang dipakai oleh ODHA dan orang yang menderita HIV dapat menunjukkan gejala penyakitnya. Meskipun demikian, mayoritas responden juga memahami dengan baik bahwa HIV dapat ditularkan melalui hubungan seksual dan transfusi darah.

Pengetahuan tentang HIV/AIDS sangat memengaruhi sikap seseorang terhadap penderita HIV/AIDS. Stigma terhadap ODHA muncul berkaitan dengan tidak tahunya seseorang tentang mekanisme penularan HIV dan sikap negatif yang dipengaruhi oleh adanya epidemi HIV/AIDS. ${ }^{14}$ Kesalahpahaman atau kurangnya pengetahuan masyarakat tentang HIV/AIDS sering kali berdampak pada ketakutan masyarakat terhadap ODHA, sehingga memunculkan penolakan terhadap ODHA. Pemberian informasi lengkap, baik melalui penyuluhan, konseling maupun sosialisasi tentang HIV/AIDS kepada masyarakat berperan penting untuk mengurangi stigma. ${ }^{19}$

Pemberian pengetahuan atau informasi terkait HIV adalah salah satu cara yang efektif untuk menjelaskan tentang pencegahan dan penularan HIV. Seseorang dengan pengetahuan yang baik dan benar terkait HIV diharapkan dapat menurunkan bahkan menghilangkan stigma pada ODHA. ${ }^{18,20}$ Persepsi masyarakat terhadap ODHA memiliki pengaruh terhadap sikap dan perilaku memberikan stigma. Hasil penelitian sebelumnya menyebutkan bahwa terdapat hubungan yang signifikan antara pemberian stigma HIV/AIDS dengan pengalaman seseorang dalam berinteraksi dengan ODHA, juga berhubungan dengan pengalaman tentang adanya rasa malu dan menyalahkan yang berhubungan dengan penyakit AIDS.21,22 Demikian juga persepsi terhadap penderita AIDS akan sangat memengaruhi cara orang tersebut bersikap dan berperilaku terhadap ODHA. ${ }^{16}$

Terkait dengan akses media informasi tentang HIV/AIDS, mayoritas responden pernah mendapatkan informasi terkait HIV/AIDS. Media televisi merupakan akses informasi yang dipilih sebagian besar responden untuk mendapatkan informasi tentang HIV. Selain media televisi, responden juga memperoleh informasi terkait HIV/AIDS melalui koran, radio, majalah, dan internet.

Media telah lama digunakan untuk memberikan informasi terkait HIV/AIDS dengan tujuan untuk meningkatkan pengetahuan, sikap, dan perilaku pencegahan penularan HIV/AIDS. Selain itu, informasi ten- tang HIV/AIDS melalui media juga memberikan dampak dalam penurunan stigma masyarakat terhadap ODHA, meskipun hal tersebut belum terjadi di semua negara dan semua kalangan masyarakat. Masyarakat di daerah perkotaan cenderung lebih banyak memanfaatkan media dibandingkan dengan masyarakat pedesaan. Kelompok masyarakat dengan akses media lebih sering memiliki stigma yang lebih rendah dibandingkan dengan kelompok masyarakat dengan akses media yang kurang. ${ }^{2}$

Duffy, ${ }^{2}$ menyebutkan bahwa tetangga merupakan seseorang yang secara hubungan sosial dekat dengan ODHA. Sikap seorang tetangga sangat penting terkait dengan pemberian stigma terhadap ODHA, karena dapat memengaruhi sikap orang lain terhadap ODHA. Stigma tersebut muncul karena tetangga beranggapan bahwa orang dengan HIV/AIDS membawa penyakit infeksi yang dapat menularkan ke orang lain dan penyakit tersebut tidak dapat disembuhkan.

Keluarga merupakan lingkungan terdekat yang berinteraksi dengan ODHA. Menurut responden, lebih banyak keluarga memiliki sikap yang positif terhadap ODHA dibandingkan dengan yang memberikan sikap negatif terhadap ODHA. Adanya perilaku keluarga yang memberikan stigma ODHA dapat memperkuat diskriminasi dan penolakan dari masyarakat. Stigma terhadap ODHA disebabkan karena keluarga merasa malu apabila mengetahui salah satu anggota keluarga adalah seorang penderita HIV sehingga ODHA juga dikucilkan dari keluarga. Ketakutan akan diperlakukan secara berbeda membuat ODHA sulit menjembatani diri dengan orang lain dan takut untuk berbagi pengalamannya, bahkan untuk menyatakan dirinya sakit. 19,23,24 Sebaliknya, dukungan atau penghapusan stigma dari orang-orang di sekitar ODHA juga akan berdampak pada peningkatan pemanfaatan pelayanan kesehatan. Dukungan sosial membuat penderita HIV tidak merasa sendiri, merasa disayangi dan mereka lebih berpeluang untuk memanfaatkan pelayanan kesehatan. Pemanfaatan pelayanan kesehatan oleh ODHA memungkinkan peningkatan pengetahuan, saling berbagi informasi terkait HIV/AIDS serta meningkatkan kepatuhan terapi antiretroviral (ARV). Keterbukaan dan rasa nyaman yang dirasakan ODHA membuat mereka lebih mudah untuk menerima informasi. 25

Selain keluarga, tokoh masyarakat merupakan salah satu faktor lingkungan sosial memiliki peranan penting terjadinya stigma terhadap ODHA. Apabila seorang tokoh masyarakat memberikan stigma terhadap ODHA, masyarakat di sekitarnya memiliki kemungkinan juga akan terpengaruh untuk melakukan hal yang sama. Reaksi masyarakat terhadap ODHA memiliki efek besar pada ODHA. Apabila reaksi masyarakat bermusuhan, seorang penderita HIV dapat merasakan adanya diskriminasi dan kemungkinan dapat meninggalkan rumah atau 
menghindari aktivitas sehari-hari seperti berbelanja, bersekolah, dan bersosialisasi dengan masyarakat. ${ }^{24}$

Pada dasarnya, tokoh masyarakat berperan penting dalam menurunkan terjadinya stigma dan diskriminasi terhadap ODHA karena tokoh-tokoh lokal merupakan model atau contoh yang biasanya menjadi panutan masyarakat, terutama pada masyarakat di daerah pedesaan. Tindakan dan sikap mereka dijadikan referensi oleh masyarakat dalam mengubah perilaku sehat, termasuk yang terkait dengan penularan HIV, dan menurunkan stigma terhadap ODHA. ${ }^{24}$ Oleh karena itu, pemberian informasi yang komprehensif tentang HIV/AIDS kepada tokoh masyarakat menjadi sangat penting dilakukan oleh petugas kesehatan, agar tokoh masyarakat dapat menularkan dan menyebarkan informasi yang benar kepada masyarakat, termasuk tentang menghilangkan stigma terhadap ODHA.

\section{Kesimpulan}

Faktor yang memengaruhi stigma terhadap ODHA di Kabupaten Grobogan adalah sikap keluarga terhadap ODHA dan persepsi responden terhadap ODHA. Keluarga dengan sikap negatif terhadap ODHA memiliki kemungkinan empat kali lebih besar memberikan stigma terhadap ODHA, sedangkan responden dengan sikap negatif terhadap ODHA memiliki kemungkinan dua kali lebih besar dalam memberikan stigma terhadap ODHA.

\section{Saran}

Perlu pemberian informasi HIV/AIDS yang lengkap kepada masyarakat untuk memberikan pemahaman yang dapat mengubah persepsi individu dan masyarakat termasuk keluarga, tetangga, dan tokoh masyarakat tentang ODHA. Selain itu, juga diperlukan upaya penurunan stigma terhadap ODHA melalui penyuluhan oleh tenaga kesehatan, sebagai contoh untuk meluruskan mitos dan penularan HIV/AIDS agar tidak terjadi kekhawatiran dan ketakutan masyarakat terhadap ODHA.

\section{Daftar Pustaka}

1. Maman S, Abler L, Parker L, Lane T, Chirowodza A, Ntogwisangu J, et al. A comparison of HIV stigma and discrimination in five international sites: The influence of care and treatment resources in high prevalence settings. Journal of Social Science \& Medicine. 2009; 68 (12): 2271-8.

2. Duffy L. Suffering, shame, and silence: the stigma of HIV/AIDS. Journal of the Association of Nurses in AIDS Care. 2005; 16 (1): 13-20.

3. Carr RL, Gramling LF. Stigma: a health barrier for women with HIV/AIDS. Journal of the Association of Nurses in AIDS Care. 2004;15 (5): 30-9.

4. Foster G, Williamson J. A review of current literature of the impact of HIV/AIDS on children in Sub-Saharan Africa. AIDS. 2000; 14: 275-84.

5. Butt L, Morin J, Numbery G, Peyon I, Goo A. Stigma and HIV/AIDS in highlands Papua. Pusat Studi Kependudukan-Universitas Cenderawasih and University of Victoria. Canada: UNCEN UoV; 2010.
6. Direktorat Jenderal Pengendalian Penyakit dan Penyehatan Lingkungan Kementerian Kesehatan RI. Laporan perkembangan kasus HIV/AIDS di Indonesia sampai triwulan II tahun 2014. Jakarta: Direktorat Jenderal Pengendalian Penyakit dan Penyehatan Lingkungan Kementerian Kesehatan Republik Indonesia; 2014.

7. Komisi Penanggulan AIDS Provinsi Jawa Tengah. Laporan kondisi HIV dan AIDS di Jawa Tengah sejak 1993 s/d Juni 2014. Semarang: Komisi Penanggulangan AIDS Provinsi Jawa Tengah; 2014.

8. Balfour L, Corace K, Tasca GA, Plummer WB, MacPherson PA, Cameron DW. High HIV knowledge relates to low stigma in Pharmacists and University Health Science Students in Guyana, South America. International Journal of Infectious Diseases. 2010; 14 (10): e881-7.

9. Li L, Wu Z, Wu S, Zhaoc Y, Jia M, Yan Z. HIV-related stigma in health care settings: a survey of service providers in China. AIDS Patient Care STDS. 2007; 21 (10): 753-62.

10. Bayer R. Stigma and the ethics of public health: not can we but should we. Social Science \& Medicine. 2008; 67 (3): 463-72.

11. Law GU, Rostill-Brookes H, Goodman D. Public stigma in health and non-healthcare students: attributions, emotions and willingness to help with adolescent self-harm. International Journal of Nursing Studies. 2009; 46 (1): 108-19.

12. Anderson M, Elam G, Gerver S, Solarin I, Fenton K, Easterbrook P. HIV/AIDS-related stigma and discrimination: Accounts of HIV-positive Caribbean people in the United Kingdom. Social Science \& Medicine. 2008; 67 (5): 790-8.

13. Darmoris. Diskriminasi petugas kesehatan terhadap orang dengan HIVAIDS (ODHA) di Rumah Sakit Provinsi Kepulauan Bangka Belitung [tesis]. Semarang: Universitas Diponegoro; 2011.

14. Herek GM, Capitanio JP, Widaman KF. HIV related stigma and knowledge in the United States: prevalence and trends, 1991-1999. American Journal of Public Health. 2002; 92 (3): 371-7.

15. Guma JA. Health workers stigmatise HIV and AIDS patients. South Sudan Medical Journal. 2011; 4: 92-3.

16. Campbell C, Nair Y, Maimane S, Sibiya Z. Understanding and challenging HIV/AIDS stigma. HIVAN Publication. Available from: http://www.lse.ac.uk/collections/socialPsicology/pdf/Challenging_HIV AIDS_Stigma.pdf.

17. Lestari TRP. Kebijakan pengendalian HIV/AIDS di Denpasar. Kesmas: Jurnal Kesehatan Masyarakat Nasional. 2013; 8 (1): 45-48.

18. Sohn A, Park S. HIV/AIDS knowledge, stigmatizing attitudes, and related behaviors and factors that affect stigmatizing attitudes against HIV/AIDS among Korean adolescents. Osong Public Health and Research Perspectives. 2012; 3 (1): 24-30.

19. Djoerban Z. Membidik AIDS: ikhtiar memahami HIV dan ODHA Yogyakarta: Galang Press; 1999.

20. Voisin DR, Bird JD, Shiu CS, Krieger C. It's crazy being a black, gay youth. Getting information about HIV prevention: a pilot study. Journal of Adolescent. 2013; 36: 111-9.

21. Hermawati P. Hubungan persepsi ODHA terhadap stigma HIV/AIDS masyarakat dengan interaksi sosial pada ODH [tesis]. Jakarta: Universitas Islam Negeri Syarif Hidayatullah; 2011.

22. Cock KMD, Mbori-Ngaca D, Marum E. Shadow on the continent: Public health and HIV/AIDS in Africa in the 21. The Lancet. 2002; 360: 67-72. 
23. Demartoto A. ODHA, masalah sosial dan pemecahannya. Jurnal Penduduk dan Pembangunan. 2006; 6 (2): 105-15.

24. Suhendi A. Peranan tokoh masyarakat lokal dalam pembangunan kesejahteraan sosial. Media Informasi. 2013; 18 (02) :105 - 16.
25. Burhan R. Pemanfaatan pelayanan kesehatan oleh perempuan terinfeksi HIV/AIDS. Kesmas: Jurnal Kesehatan Masyarakat Nasional. 2013; 8 (1): $33-8$. 